\title{
Marketing ethics and the marketing mix: managerial issues
}

\author{
R. Abratt
}

Department of Business Economics, University of the Witwatersrand, Jokannesburg, Wits, 2050 Republic of South Afriea

Marketing, more so than any other business discipline, has been criticized by people for hurting consumers, society as a whole, and other business firms. Deceptive prices, high advertising and distribution costs, highpressure selling and unsafe products are common complaints. This article reviews some of the issues involved. It deals with marketing ethics and its problems and then discusses the role of ethics in the marketing mix. The article calls for marketers to adhere to ethical standards of conduct or face the consequences.

Bemarking is al in die verlede daarvoor gekritiseer dat dit, in ' $\mathrm{n}$ groter mate as die ander besigheidsdisiplines, verbruikers, die groter gemeenskap en ander besigheidsondernemings benadeel. Algemene klagtes wat ingebring word, is onetiese prysstrategieë, hoë advertensie- en verspreidingskoste, hoë-druk verkoopstegnieke en die verkoop van gevaarlike produkte. Hierdie artikel bied 'n oorsig van 'n aantal van die vraagstukke wat hierby betrokke is. Bemarkingsetiek, die probleme hieraan verbonde en die rol van etiek in die kombinasie van die vier bemarkingsbeleidsinstrumente word bespreek. Die slotsom is dat bemarkingspratisyns etiese norme sal moet handhaaf of die gevolge sal moet dra.

\section{Introduction}

Is marketing defensible from a moral, social, and economic perspective? Two fundamental premises underlie any discussion of the role of marketing in a free enterprise economy.

Firstly, it is assumed that a high standard of living is a valid goal. Secondly, profit is assumed to be an accurate measure of the extent to which business enterprises have succeeded in meeting consumer desires and thereby contributing to a rising living standard (Abratt \& Sacks, 1988).

Ethics is frequently a grey area, because of differences in people's perceptions of what constitutes an unethical practise. The ability of an enterprise to monitor ethical performance depends upon the establishment of objectives for ethical behaviour. Charging fair prices, manufacturing safe products, and using truthful advertising are worthy objectives.

The objective of this article is to review ethics from a marketing management point of view.

\section{Business ethics}

'... when the manufacture of a certain product can be linked eventually to human disease or a decrease in the quality of human life, then the issues surrounding it are no longer simply traditional 'business' issues. No amount of expertise in marketing, accounting or management can deal adequately with such problems ... Nor can situations like these be reduced simply to legal problems '(Donaldson \& Werhane, 1983).

Ethics are concerned with doing good, or the right thing in a given human situation (Wilson, 1975). Business ethics are concerned with an evaluation of business practices in the light of some concept of human value, it looks at corporate profits not for their own sake but with respect to the achievement of some human good.

Carroll (1981), whilst recognizing that social responsibility issues do have ethical dimensions, distinguishes social responsibility and business ethics on the basis that the former is primarily an organizational or corporate concern, whereas the latter is the concern of the individual manager or business decision-maker. This distinction is, however, by no means universally accepted and debate still continues as to whether corporations, because they are artificial creations, can be said to have social responsibilities at all or whether the term is only applicable to individuals within the organization.

Bartels (1967), in developing his model for ethics in marketing, regards ethics as referring to a standard in terms of which business action can be judged 'right' or 'wrong' - not in an absolute sense, but relative to another entity whose perceptions have either been violated or fulfilled.

These various explanations of the field of business ethics indicate that the distinction between social responsibility and business ethics is not easily made, certainly not insofar as their application to the societal marketing concept is concerned. Thus while certain aspects of social responsiblity may be discretionary such as donations to charitable institutions - and therefore their non-fulfilment cannot be regarded as 'wrong' or 'unethical', other aspects of social responsibility are clearly based on obligatory standards of behaviour which, if isolated, can certainly be labelled as unethical (Carroll, 1981).

Perhaps ethical responsibilities are only one facet of a wider range of responsibilities known as 'social responsibilities'.

\section{The marketing mix}

The marketing mix is the set of controllable variables that must be managed to satisfy the target market and achieve organizational objectives. These controllable variables are usually classified according to four major decision areas: product, price, place, and promotion. Promotion consists of advertising, selling, sales promotion, and public relations elements. Like many concepts, the marketing mix concept seems relatively simple, once it has been expressed. However, the necessity of integration in marketing thinking is ever 
present. Changing an advertising campaign could have a bearing on the price to be charged for the product and the place where it could be purchased. In addition, many decisions that managers take have an ethical and social dimension. Ethical issues in the various elements of the marketing mix will now be discussed.

\section{Product}

The quality of goods can be measured in respect of four distinct properties, i.e. ineffectiveness, reliability, durability, and safety. It is generally felt that even if suppliers make no specific claims in respect of these properties, consumers are entitled to expect a certain minimum quality with respect to them. In considering durability there is some feeling that obsolescence is built into some products to ensure a continuous market.

When considering these four properties of products, safety is the topic which gives rise to the most intense discussion. This topic lies at the very centre of ethics as it may affect people's health and livelihood or even their lives. However, the responsibility for the safety of a product does not always rest solely with the supplier. Certain goods such as explosives and knives are inherently dangerous. Others such as bicycles may bring the consumer into dangerous situations. Still others could be dangerous if used incorrectly, injudiciously or abnormally. Responsibility for safety is shared if the consumer is aware of, or can anticipate, the dangers involved. If the consumer can in no way anticipate any danger involved with the product then the responsibility for safety rest with the supplier (Braybrooke, 1983).

The level of quality in respect of effectiveness, reliability, durability, and safety has to be balanced against the cost of obtaining that level. The cost of complete safety in all products would be far higher than that which the consumer would be prepared to pay, therefore an equilibrium point is sought (Viscusi, 1985).

The technology of production and or the use of products can lead to harmful effects on health, environment, and culture. An obvious example is cigarettes which can effect the health of non-smokers as well as smokers. The mining and smelting of metal ore causes a great deal of pollution. TV has had a big influence on people's social lives. The effects of the production of, and the use of products, especially the cumulative effect of large numbers of products, needs to be balanced against the cost to health, environment, and culture. Increased awareness of the need for environmental protection means that firms should become proactive and include consideration of social and environmental factors when evaluating new products. Although consideration of these factors may lead to increased product development costs this should be offset by an increased probability of obtaining capital and winning contracts, and the development of a good company image (Varkle, 1972). The effect of products should also be evaluated in terms of the target market. Products that have no serious harmful effects in one market may prove harmful in another market. An example of this is the introduction of infant formulas into the third world (Donaldson \& Werhane, 1982).

Some products by their very nature are life-sustaining/ saving products. Under certain circumstances the need for these products could be at a premium. Companies should be very careful in these cases not to take advantage of the need for their product and tarnish their image by making large profits (Braybrooke, 1983).

There are various forces which help to control and regulate the quality of goods offered to the market place. The first of these is self-respect. Generally speaking, to have self-respect implies that one believes one has the respect of others. Would this be possible if one were involved in the production of inferior goods in any way? Would one be able to have any pride in one's work and life if involved in the making and selling of goods which one knew were not effective, reliable, durable and safe? (Braybrooke, 1983).

The other two methods of control are market forces and legal (government) regulations.

It is believed that the market forces can exert a powerful degree of control over the quality of goods. However, this depends greatly on the level of information available to the consumer. It is felt that information should be impartial and therefore available from a source other than the firm and their advertising agency. Sometimes information is supplied by the government who define certain grades for products, e.g. meat. Should a supplier incorrectly grade his goods he would be committing fraud and therefore liable to legal action.

Market forces control quality by 'switching brands' if dissatisfied with a product, e.g. Tylenol lost $87 \%$ of its market after poisoning of Tylenol capsules resulted in seven deaths. Market forces also control quality by 'word-of-mouth' communication of dissatisfaction. Market forces can control quality of production by boycotting firms identified as causing harmful effects on health or environment (Donaldson \& Werhane, 1983; Viscusi 1985; and Sacks \& Abratt, 1986). Although it would perhaps be desirable for market forces to control quality in all cases, there are situations when it may be necessary for government to enforce regulations, e.g. pollution. To be effective, government regulations should work with and complement market forces. Noncompliance with regulations should have a similar financial incentive similar to those the market place would generate. Government should recognize that there are trade-offs between quality and cost. Government must find a balance between stringency and effectiveness of regulations, e.g. in the USA the FDA's pharmaceutical testing programme is so stringent that they run the risk that a beneficial drug will reach the market slowly or maybe not at all (Viscusi., 1985). In South Africa no formal research into this issue has been undertaken.

Despite due care to quality there will always be occasions when a product fails to satisfy a consumer. In response the consumer may seek redress through a complaint. Studies have shown that the handling of dissatisfied customers is very important (Pitt \& Abratt, 1984; Diener \& Greyser, 1978). If a customer's 
complaint is not handled to his/her satisfaction he/she is likely to 'switch brands' and engage in negative word of mouth communication. If a customer is satisfied with the handling of his/her complaint, evidence suggests that he/ she will be more loyal than before and will engage in positive word-of-mouth communication. Consumer complaints should also be seen as opportunities for design ideas and as contributing to quality control. Studies show that many companies fail to use consumer complaint management to its full potential (Rousseau, 1987; Richins, 1987).

As the consumer becomes more informed and aware of the effects of production technology and the use of products, market forces will demand acceptable levels of quality. As business becomes more and more competitive a company's reputation for quality production, products and services will become essential to their very survival.

\section{Price}

Is there such a thing as fair price? Only if the answer is 'yes' can one proceed to discuss price ethics at all. The question of the morality of making profit at all arises in price ethics as well.

Profit in itself is too complex an issue to try and use it to establish a company's ethical stance on prices, and yet we have an instinct for what are 'ill gotten gains' and what is 'a profit' (Camenisch, 1987). Firstly, a profit must be earned. Secondly, it must be fairly and justly earned. Finally, a profit must be reasonable.

It is clear that to establish exactly what amount is a 'fair profit' requires some interaction between buyer and seller. Thus the amount of profit could be determined by either 'whatever the market will bear', i.e. normal market forces. However, such controlling mechanisms are limpeded and obstructed and sometimes defeated by monopoly, oligopoly and government intervention', or the 'business's own conscience to keep it within appropriate limits'. These limits are determined by 'Some contribution of business and/or its owners, for which the profit is an appropriate repayment or reward'.

It is possible to demonstrate that there is a unique price, which satisfies the definition of 'just price', where the buyer and seller are given equal opportunity of reaching a justified standard of living' (Hagg, 1983). Therefore, if one begins with the premise that all people have the right to an equal standard of living, there is such a thing as a 'just price' and any deviation from this price will in the long term lead to some form of buyer dissatisfaction. The pressure from this dissatisfaction results ultimately in legislation to prevent exploitation, reforms within the company, or the demise of the company (Sonnefeld, 1978).

Even in the 'ignorant' third world countries where capitalism exists in conditions of acute shortage of basic goods and prices are high, central planning is deemed ultimately necessary (Kwame, 1983).

Free market forces do not always result in equilibrium prices and traded volumes, and therefore the temptation for 'competitors' to fix high prices, earn more revenue and get away with it, albeit in the short term, is very strong. Economists suspect oligopolies of conspiring to collusion, yet it appears to be the crowded, mature markets with undifferentiated products where it occurs (Sonnefeld, 1978).

Many competitors in this situation conclude that the only way to survive is to agree to fix prices.

Corporate culture aggravates the situation. Many firms believe their corrupt ethics are the norm, as they have been part of the business for years. Price agreements with competitors are the quickest way of profit building and getting these rewards.

Decentralized price-setting policies make it difficult for senior managers to control collusion, while trade associations make it easier for competitors to compare notes and agree to fix higher prices (Lawyer, 1963). All of this reinforces junior managers' belief that this unethical behaviour is the norm, and worse, perceive it to be top management's intent. And so, given time, unethical pricing behaviour becomes the market sector norm.

Ironically, price itself can be used as a product discriminator to achieve higher sales, as opposed to merely wishing to get a larger revenue. It is natural to expect that in a normally functioning market, one would find a high degree of positive relationship between product quality and price, and get 'value for money'. A high price should either reflect a high demand for superior goods or high cost of producing superior goods. However, buyers are often unable to make quality comparisons among brands, and sellers are aware of this and may 'convey false market signals' (Gerstner, 1985). The only inhibitors to sellers are the desire for repeat sales and informed customers.

It is expected that the product/price relation would be positive and strong for frequently purchased, lower priced items, because sellers are dependent on resales. Despite these ethical inhibitors, several studies have shown that the product/price relations are product specific and weak in general (Gerstner, 1985). Where the items are high priced, the product/price relation is stronger, as the buyer is more likely to be more informed. It is suggested that higher prices could be supported for products which inform the buyer of quality, resulting in positive word-of-mouth information.

This is supported by studies showing the positive relationship between price and information given (Miller, 1987). However, this study also suggests that the product/price relation breaks down when too much information is available. Also, if the product is associated with a store, the store's image affects the product's perception more than its price.

The question of price/quality ethics is not clear, other than to say that the seller should be aware of ultimately being accused of unreasonable prices or poor products. One could also imagine 'information wars' similar to price wars being ultimately detrimental to buyer and seller.

In summary on the ethics of price one can say that there definitely are fair profits and just prices, assuming 
that all people have a right to an equal standard of living. Price deviation or unethical practices such as price fixing and false market signals are not exposed by free market forces in the short term. In the long run, however, unethical practices will be detrimental to the company and country, and will result in legislation by government control, ethical reforms within the company (for survivial), or the company going under.

\section{Promotion}

\section{Advertising}

Perhaps before the thoughts and conclusions of different authors about the rights and wrongs in advertising are analysed we need to look at the aims and objectives of the advertisers, and perhaps the needs and aspirations of the consumer, and not to forget the standpoint of the legislators and various consumer protection organizations.

Theodore Levitt (1970) stated that a well-known designer of cosmetic packaging is primarily interested in creating images to help separate the unwary customer from his loose change, because at the same time advertisements reflect the symbols of man's aspirations. In the same light then, Charles Revson of Revlon, the well-known range of cosmetics, suggested the distinction that, in the factory we make cosmetics, in the store we sell hope'.

Obviously then, while businessmen are primarily involved in the business of making profit, it is the extent to which the advertisers go in distorting and blatantly deceiving the consumer that prompts the actions of the legislators and consumer protection groups. People, they say, want less fluff and more fact about the things they buy. Levitt goes on to describe the consumer as an amateur, an impotent midget, while the producer is a powerful giant. It is, therefore, an uneven match.

\section{Alcohol and advertising}

The facts state that alcohol consumption has been firmly entrenched in civilization for thousands of years and has been used for medicinal purposes, as well as for flavouring food and it is also part of some religious rituals (Abratt \& Sacks, 1986).

Because of its powerful effect on certain users it has been responsible for much of the misery and degradation in human life. The effects of alcohol abuse reach deeply into our whole social structure and the results of alcoholrelated motor accidents and family trauma are known to most of us.

Most countries therefore, have some form of restriction on liquor advertising, while others ban it totally. The effects of these bans and restrictions are uncertain. As with cigarettes in the USA and the United Kingdom, there was a growing pressure on the authorities in these countries to introduce legislation controlling the advertising of alcoholic beverages (Abratt \& Sacks, 1986).

In South Africa, legislation concerning the liquor industry is less extensive than that of other countries, where they have laws governing the marketing of liquor.
In South Africa self-regulation is practised through the Advertising Standards Authority code. The effects of bans and restrictions are still uncertain. Many studies have not proven the case for or against, and even if these laws were effective in reducing consumption, it is not certain that they would reduce alcohol-related problems.

Advertising directed at specific, vulnerable segments of the population.

'The effects of T.V. advertising on children have caused a great deal of controversy' (Varkle, 1978). He discusses some of the broader implications for resolving conflict among marketers, consumer groups and regulatory agencies.

Much of the controversy concerns advertising during children's prime viewing time and the subject of advertising and children has become a major issue in the activities of the Federal Trade Commission.

Rules proposed at that time would effectively ban advertising directed at children during their prime viewing time, a ban on advertising of products that contain more than a specified amount of sugar, and sponsoring of health and nutritional disclosure messages with food advertising that is directed at children.

The issues which are in dispute here are:

- whether the aim is to regulate the products themselves or the advertising;

- critics have pointed out the fact that cigarette consumption for example, actually increased since the

$T$.V. advertising ban, and that sugar consumption has changed little since the advent of T.V.;

- children watch T.V. at all times of the day and their abilities to evaluate claims are age related.

This raises the suggestion that children are then particularly vulnerable to manipulation by irresponsible advertisers, and the author feels that critics as well as advertisers should supplement their concern with attention to the children whose views of society are the most easily affected.

\section{Regulation in advertising}

Most regulation codes are based on the original which was introduced in 1936 - The International Code of Standards of Advertising Practice, which was drafted by the International Chamber of Commerce Committee.

In most other countries regulation is strictly controlled by legislation, where penalties are imposed. In South Africa it is a form of self-regulation imposed by the Advertising Standards Authority and member bodies (Sacks \& Abratt, 1986).

The main regulatory body in South Africa then, is the Advertising' Standards Authority which was formed in 1969 , to preempt the imposition of a state body, and it has been successful. South Africa is the only country in the world where there exists a voluntarily imposed regulatory control (Sinclair 1985). The A.S.A. is an independent body funded by the advertising industry. It is made up of a group of member organizations such as the S.A.B.C, the Newspaper Press Union, and approximately 18 other similar organizations. The 
association can sanction the witholding of advertising space or time from advertisers and the withdrawal of trading privileges. This is applied through its members.

In the preface of the code, advertising is defined as being a service to the public and as such should be informative, factual, honest, decent and its content should not violate the laws of the country.

The code is based on the British code of Practice and the International Code of Advertising Practice.

\section{Selling}

\section{Morals, bribery and selling method}

'To obtain favours, pay-offs are made. To gain special rights gifts are given. Corruption exists to some extent in all cultures, under all market systems and in all countries. In some cases governments and businesses depend on it for their existence. In others, it is condemned, despised and criticized but never really eradicated' (Pitt \& Abratt, 1986).

Are management attitudes right? The basic attitude (moral standards) of the community has to be considered as to what is wrong, acceptable or right. It is very difficult to make a clear cut separation, because what is right for one, will be totally wrong for another. This is how a country's culture and religious background can affect certain issues. It is viewing the same subject through different filters and obtaining totally different images every time.

A study carried out by Pitt \& Abratt (1986) highlighted this problem of perception very well. It was found that the words used to describe a specific situation could sway an opinion from one end of the scale to the other, for e.g. a gift of relative insignificance to one income group, could be a major gift to another. The question is what is the generally accepted norm.

'Bribery can be considered as a business arrangement pure and simple with corporate employees or government officials selling friendly decisions'. Once again the filter through which one views the above can either add a positive or a negative feeling (Johnson, 1985). In general, return of favours are considered as being neighbourly. But in those instances, both parties pay a price for a certain amount of gain. But in the actual case stated, both parties gain at the expense of a third party. The company or Government Institution has to pay for the bribe that was received by the buyer, as well as for a higher profit margin on behalf of the seller. This price could even extend further into the quality of the product or service rendered.

A further statement by Johnson (1985) is 'Morality in business has been called a tremendous social asset, for without trustworthy participants market transactions costs sharply increase. With bribery citizens and or stockholders experience losses as their agent makes decisions for personal benefit'.

The above can have a major impact on the society's welfare, in that prices and profits are unrealistically high. These high prices take away the major advantage of free enterprise where price levels are dictated by supply and demand. Johnson calls this type of action sabotage to the general economic welfare and principles. 'It harms competitors without helping consumers'.

\section{Distribution}

Ethical issues often arise between manufacturers and their resellers (wholesalers and retailers). Suppose a manufacturer promises to give a retailer exclusive distribution in a trading area, and then breaks this promise, or suppose a manufacturer plans to discontinue making a particular product. Is the manufacturer ethically obligated to tell its resellers far in advance so they can sell off their inventories?. Should retailers, in turn, advise their customers that the product will soon become unavailable? Research into the ethics of distribution is limited but should be carried out in future in an attempt to address these questions.

\section{Marketing research}

According to Tybout \& Zaltman (1974) the significance of ethics in marketing research is increasing due to the expanding domain of marketing research and the greater use of experimentation as a research tool. The use of experimentation raises ethical issues that were previously the domain of psychologists and sociologists. There are few ethical guidelines to assist the marketing researcher. The AMA marketing research code focuses on the client-researcher relationship but ignores the subject-researcher relationship which is of importance in experiments. 'An understanding of ethical issues involved in marketing research is essential for producing quality research'. Tybout \& Zaltman (1974) discusses the basic rights of subjects, and the effects that violation of these rights may have on the quality of data collected.

Violation of the subject's right to choose may result in feelings of forced compliance and hence to biased data, it may violate the subject's desire for anonymity, and may lead to the subject's refusal to participate in future research. Violation of the subject's right to safety (freedom from psychological or physical harm) could take the form of violation of anonymity, subject stress, or deception. In each case violation of rights could lead to biased data and refusal to participate in future research. Violation of the subject's right to be informed could result in unrelieved stress, feeling of being used, distorted responses, and refusal to participate in future research.

If subject's rights are continually violated, the result could be a boycott of marketing research or legislation restricting marketing researchers.

Hunt, Chonko \& Wilcox (1984) investigated the ethical problems facing marketing researchers. Their findings suggested nine conclusions.

1. Marketing researchers' most difficult ethical problem concerned the integrity of their work.

2. In-house researcher's main problems were balancing self-interest against the interest of other parties and against company interest.

3. Agency researchers were faced with the problem of balancing clients' interests against those of company, self, society and other clients. 
4. Marketing researchers perceive many opportunities for unethical behaviour, but perceive a low frequency of unethical behaviour.

5. Marketing researchers do not believe that unethical behaviour generally leads to successful research.

6. A large proportion of marketing researchers believe that successful managers engage in unethical behaviour.

7. The action of top management is an important factor in reducing the ethical problems of marketing researchers

8. The existence of codes of conduct seems to be unrelated to the incidence of ethical problems in marketing research.

9. The American Marketing Association code of conduct does not cover many of the issues faced by marketing researchers

They recommended that the existing codes of ethics be revised to address the issues faced by marketing researchers, that top management make it clear that unethical behaviour will not be tolerated and that marketing research executives ensure that they are aware of the ethical problems in their organizations.

\section{Conclusion}

Marketing interacts with the society it serves. It can have both positive and negative effects on such areas as the quality of life and consumer expectations. Ethical behaviour, based on honest and proper conduct, is a requirement for proper marketing management. Marketers who accept their social responsibility adhere to ethical standards of conduct. Those who do otherwise invite further government regulation of marketing activities.

\section{References}

Abratt, R. \& Sacks, D. 1988. The Marketing Challenge Towards Being Profitable and Socially Responsible. J. Bus. Ethics, vol.7, 497-507.

Bartels, R. 1967. A Model for Ethics in Marketing. J. Market., vol.31, 21.

Braybrooke, D. 1983. Ethics in the World of Business. Totowa: Rowman and Allanheld.

Camenisch, P.F. 1987. Profit - Some Moral Reflections. J. Bus. Ethics, vol.6, April, 225-231.

Carroll, A.B. 1981. Business and Society. M S: Little, Brown and Company.

Diener, B.J. \& Greyser, S.A. 1978. Consumers views of redress needs. J. Market., vol.42, October, 21-27.
Donaldson, T. \& Werhane, P.H. (Eds.) 1983. Ethical Issues in Business. Englewood Cliffs, N.J.: Prentice Hall.

Gerstner, E. 1985. Do Higher Prices Signal Higher Quality? J. Market. Res., vol. XXII, May, 209-215.

Hagg, C. 1983. Just Prices and Equal Opportunity. J. Bus. Ethics, vol.2, 269-272.

Hunt, S.D., Chonko, L.B. \& Wilcox, J.B. 1984. Ethical Problems of Marketing Researchers. J. Market. Res., vol.21, August, 309-323.

Johnson, H.L. 1985. Bribery In International Markets? Diagnosis Clarification and Remedy. J. Bus. Ethics, vol. 4, 447.

Kwame, S. 1983. Doing Business In An African Country (Business Ethics and Capitalism In a Poor Country). $J$. Bus. Ethics, vol.2, 263-268.

Lawyer, J.Q. 1963. How to conspire to Fix Prices. Harv. Bus. Rev., March-April, 95-103.

Levitt, T. 1970. The Morality of Advertising. Harv. Bus. Rev., July-August, 84-92.

Miller, J.B. 1987. Does Competitive Information Affect the Results of Concept Test? J. Advert. Res., April/May, 116-24.

Pitt, L.F. \& Abratt, R. 1984. Customer Dissatisfaction - does the consumer seek redress? S. Afr. J. Bus. Mgmnt., vol.15, 179-181.

Pitt, L.F. \& Abratt, R. 1986. Corruption in Business - Are Management Attitudes Right? J. Bus. Ethics, vol.5, February, 59.

Richins, M.L. 1987. A Multivariate /analysis of Responses to Dissatisfaction. J. Acad. Market Sci., vol. 15, $24-31$.

Rousseau, g.G. 1987. Consumer and Retailer Perceptions of Market Transactions and the Complaining Consumer. $J$. Industr. Psychol., vol. 13, 1-5.

Sacks, D. \& Abratt, R. 1986. The Moral Minefield: Legal and Social Issues of tobacco and Liquor Marketing. S. Afr. J. Bus. Mgmnt., vol.17, 182-190.

Sinclair, R. 1985. Make the Other Half Work Too. A Text on Advertising in South Africa. Johannesburg: MacMillan South Africa.

Sonnefeld, J. 1978. Why Companies Succumb to Price Fixing? Harv. Bus. Rev., July/August, 145-157.

Tybout, A.M. \& Zaltman, G. 1974. Ethics in Marketing Research: Their Practical Relevance. J. Market.Res., vol.XI, November 337-368.

Varkle, L.D. 1972. Social and environmental Considerations in New Product Development. J. Market., vol. 36, October, 11-15.

Viscusi, W.K. 1985. Market Incentives for Safety. Harv. Bus. Rev., July/August, 133.

Wilson, J.A. 1975. Morality and the Contemporary Business System. J. Contemp. Bus., vol.4, 31-58. 